\title{
Analisis Sebaran Salinitas Pasca Pembangunan Tanggul Wonokerto Sungai Bedahan Kabupaten Pekalongan
}

\author{
Bima Andriantama $^{1 *}$, Petrus Subardjo ${ }^{1}$, Gentur Handoyo ${ }^{1}$, Kunarso $^{1}$ \\ dan Agus Anugroho Dwi Suryoputro ${ }^{1}$ \\ ${ }^{1}$ Departemen Oseanografi, Fakultas Perikanan dan Ilmu Kelautan, Universitas Diponegoro \\ Jl. Prof. H. Sudarto, S.H., Tembalang, Semarang 50275 Telp/Fax (024)7474698 \\ Email: *driantbima@gmail.com
}

\begin{abstract}
Abstrak
Kabupaten Pekalongan merupakan wilayah yang terletak di bagian utara Pulau Jawa yang berbatasan langsung dengan laut Jawa yang banyak terdapat sungai yang bermuara langsung menuju Laut Jawa, salah satunya Muara Bedahan. Pada lokasi penelitian terdapat tambak, Tempat Pelelangan Ikan dan sebagai jalur pelabuhan kapal nelayan. Masyarakat pesisir setempat mengandalkan pasokan air payau dari aliran Sungai Bedahan, namun mereka kesulitan memperoleh air bersih sebelum Tanggul Wonokerto dibangun. Tujuan dari penelitian ini adalah untuk mengetahui pola sebaran salinitas sesaat dan sebelum Tanggul Wonokerto selesai dibangun. Penelitian ini dilakukan pada Februari 2020 dan Juni 2020 saat kondisi surut menuju pasang. Variabel yang diamati yaitu data utama berupa data salinitas, kedalaman, dan pasang surut. Titik stasiun penelitian tersebar dari sungai dekat pemukiman penduduk hingga perairan muara. Data yang diperoleh selanjutnya diolah menggunakan ODV 4 dan dianalisis secara deskriptif. Hasil penelitian menunjukkan bahwa Muara Bedahan memiliki pola distribusi salinitas di wilayah hulu penelitian hingga tanggul, sebelum tanggul jadi di permukaan (0,2D) rata-rata sekitar 11,47 ppt dan di lapisan dasar (0,8D) 15,44 ppt. Setelah tanggul jadi dipermukaan (0,2D) rata-ratanya 11,2 ppt dan di lapisan dasar (0,8D) 15,4 ppt. Kedalaman maksimum lokasi penelitian $4 \mathrm{~m}$ dengan tipe pasang surut wilayah Pekalongan campuran condong harian tunggal.
\end{abstract}

Kata kunci : Salinitas, Pasang Surut, Muara, Tanggul, Pekalongan

\begin{abstract}
Pekalongan Regency is an area located in the northern part of Java Island which is directly adjacent to the Java Sea, where there are many rivers that lead directly to the Java Sea, one of which is Bedahan Estuary. There are ponds, fish auction place, and fishing boat port route at the research location. Local people rely on brackish water supplies from the Bedahan River, but they had difficulty getting clean water before the Wonokerto dike was built. The purpose of this study was to determine the pattern of salinity distribution shortly before the Wonokerto dike was completed. This research was conducted in February 2020 and June 2020 when conditions recede towards high tide. The variables observed are salinity, depth, and tidal data. The research station points are spread out from the river near residential areas to the estuary. The data obtained were processed using ODV 4 and analyzed descriptively. The results showed that Bedahan Estuary had a salinity distribution pattern before the dike was formed on the surface $(0,2 D)$ an average of 11,47 ppt and 15,44 ppt in the bottol layer (0,8D). After the dike is finished, the average at the surface (0,2D) is 11,2 ppt and 15,4 at the bottol layer $(0,8 D)$. The maximum depth of the research location is $4 \mathrm{~m}$ with mixed single daily incline tidal type.
\end{abstract}

Keywords : Salinity, Tides, Estuary, Dike, Pekalongan

\section{PENDAHULUAN}

Kabupaten Pekalongan merupakan wilayah yang terletak di bagian utara Pulau Jawa yang berbatasan langsung dengan laut Jawa, sehingga wilayah utara Pekalongan banyak terdapat sungai yang bermuara langsung menuju Laut Jawa. Banyaknya sungai yang bermuara di Laut Jawa ini dimanfaatkan untuk berbagai kegiatan aktivitas manusia mulai dari untuk memenuhi kebutuhan hidup, sekadar berkumpul bersama, hingga tempat pariwisata. Salah satu sungai yang cukup terkenal 
di Kabupaten Pekalongan yaitu Sungai Bedahan. Sungai Bedahan merupakan salah satu sungai di Kabupaten Pekalongan yang memiliki muara yang bercabang yang semuanya mengalir dari selatan ke utara dan bermuara di Laut Jawa. Sungai Bedahan bertemu dengan Sungai Sragi Baru dan bermuara di Muara Bedahan yang dijadikan sebagai jalur perlintasan para nelayan dan Tempat Pelelangan Ikan (TPI). Selain itu, Muara Bedahan ini juga biasa dimanfaatkan penduduk setempat sebagai tempat memancing, menjemur udang-udang kecil seperti udang rebon, aliran irigasi, dan aktivitas umum sehari-hari bagi penduduk pesisir setempat.

Pada wilayah Sungai Bedahan, terdapat tanggul tertutup, Tanggul Wonokerto, yang membentang sepanjang 7,2 km di Kecamatan Wonokerto dengan bagian ujung barat terdapat Rumah Pompa Silempeng dan ujung timur terdapat Rumah Pompa Sengkarang. Tanggul Wonokerto ini memiliki sistem polder namun berbentuk longstorage karena memotong wilayah luas yang memanjang dan kedua ujungnya diberikan pompa. Berdasarkan Peraturan Menteri Pekerjaan Umum Republik Indonesia Nomor 12/PRT/M/2014 Tentang Penyelenggaraan Sistem Drainase Perkotaan, sistem polder ini merupakan sistem penanganan drainase dengan cara mengisolasi daerah yang dilayani dari pengaruh limpasan air laut, air hujan, maupun limpasan dari prasarana lain yang terdiri dari kolam penampung, sistem drainase, dan perpompaan. Tanggul ini dapat mempengaruhi tinggi muka air sungai hingga air laut yang dapat bercampur dengan air tawar yang berasal dari aliran sungai pada ekosistem estuari. Selain itu, berdasarkan lembar peta Rupa Bumi Indonesia (RBI) skala 1:25.000 lembar 1409-113 publikasi BIG tahun 2017 terdapat banyak cabang sungai yang bermuara di Muara Bedahan yaitu Sungai Sragi Baru, Sungai Bedahan, dan Sungai Merican, yang ketiganya melewati TPI Wonokerto sehingga bawaan aliran air yang menuju laut dari arah sungai dapat mempengaruhi kadar salinitas.

Pada lokasi penelitian terdapat banyak tanaman mangrove dan tambak yang berada di bagian sisi kanan dan kiri Sungai Bedahan sampai menuju muara di TPI Wonokerto. Para petani dan petambak ini mengandalkan pasokan air payau dari aliran Sungai Bedahan, namun mereka kesulitan memperoleh air payau pada saat musim penghujan tiba. Penelitian ini diharapkan dapat mengetahui pola sebaran salinitas pada akhir musim barat dan musim timur di perairan muara Sungai Bedahan secara vertikal dan horizontal, sehingga perbandingan hasil penelitian diharapkan dapat memberikan informasi mengenai kelayakan kualitas lingkungan perairan Muara Bedahan yang diharapkan dapat menjadi acuan bagi pemerintah, masyarakat pesisir setempat, hingga akademisi untuk penelitian dan pengembangan budidaya pesisir.

\section{MATERI DAN METODE}

Penelitian ini dilaksanakan pada 26 Februari 2020 dan 18 Juni 2020 di perairan Muara Bedahan, Kabupaten Pekalongan. Materi penelitian meliputi data primer yang langsung diambil saat survei lapangan yang berupa data salinitas, kedalaman perairan, pasang surut bulan Juni 2020, dan titik koordinat stasiun. Data sekunder meliputi data pasang surut hasil pengukuran BIG bulan Februari 2020, Peta Rupa Bumi Indonesia lembar 1409-113 dan 1409-114 skala 1:25.000 publikasi BIG tahun 2017, dan Citra Satelit Google Earth tahun 2020.

Metode yang digunakan dalam penelitian ini adalah metode kuantitatif yang menurut Sugiyono (2009) merupakan metode ilmiah karena memenuhi kaidah-kaidah ilmiah secara empiris, obyektif, terukur, rasional, dan sistematis. Metode kuantitatif merupakan metode yang menggunakan angka seperti pengolahan data yang dilakukan pada penelitian ini, dimana pengolahan data salinitas dan kedalaman berupa angka yang dikonversikan kedalam grafik melalui perangkat lunak sehingga memudahkan data untuk diinterpretasi dan dianalisis.

Metode penentuan lokasi menggunakan purposive sampling method, yaitu berdasarkan pada penentuan lokasi yang mempertimbangkan ciri-ciri khusus yang sesuai dengan tujuan penelitian yang dapat mewakili kondisi daerah penelitian keseluruhan sehingga dapat ditarik suatu kesimpulan (Sudjana, 1992). Meetode penentuan stasiun dimulai dari pemukiman sebelum Tanggul Wonokerto di Sungai Bedahan sebagai titik awal samping pada titik 1 hingga Muara Bedahan pada titik 21, yang diharapkan dapat mewakili gambaran lokasi penelitian dengan jarak mencapai $3 \mathrm{~km}$. Hal ini diharapkan dapat dengan jelas mewakili perubahan nilai salinitas tertinggi sampai batas $0 \%$ atau mencapai perbatasan pemukiman yang telah melewati Tanggul Wonokerto seperti pada Gambar 1. 


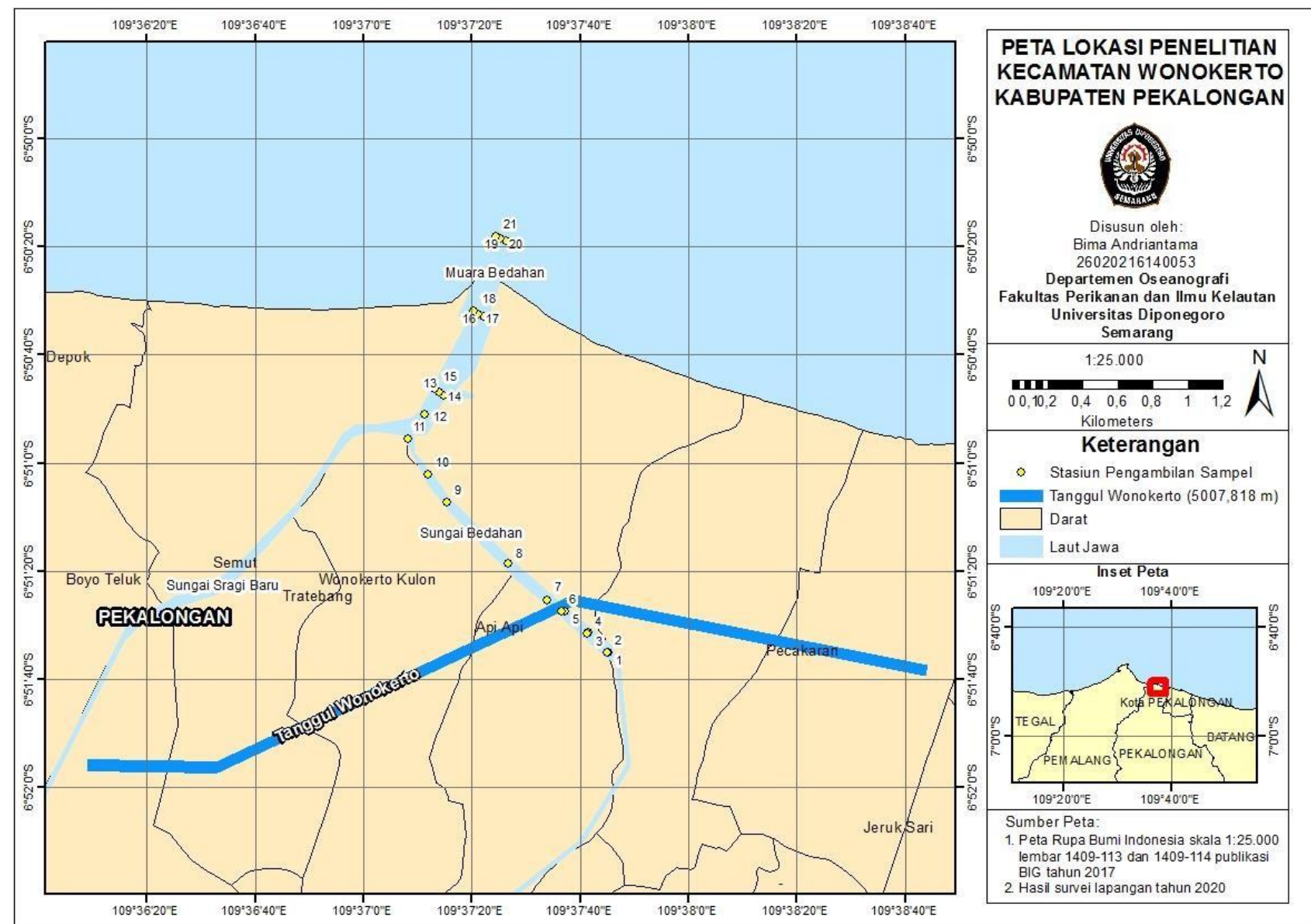

Gambar 1. Peta Lokasi Penelitian

Pengamatan pasang surut dilakukan selama 15 hari pada Juni 2020 dengan interval 1 jam menggunakan tide logger dan selanjutnya dianalisis dengan metode Admiralty sehingga diperoleh komponen dan tipe pasang surut diperairan tersebut untuk dibandingkan dengan hasil metode Admiralty yang diperoleh berdasarkan data pengamatan BIG Februari 2020 sebelum Tanggul Wonokerto selesai dibangun.

Pengukuran salinitas dilakukan secara vertikal dengan menggunakan refraktometer di setiap stasiun dari lapisan permukaan $(0,2 \mathrm{~d})$ dan lapisan dasar $(0,8 \mathrm{~d})$ yang dianggap cukup mewakili (Triatmodjo, 2008) nilai salinitas perairan ini yang diolah menggunakan ODV 4 sekaligus data kedalaman untuk mengetahui tipe estuari sebagai langkah awal mengetahui bagaimana percampuran di lokasi tersebut dan pengaruhnya terhadap pembangunan Tanggul Wonokerto di wilayah tersebut.

\section{HASIL DAN PEMBAHASAN}

\section{Salinitas Muara Bedahan Sebelum Tanggul Selesai}

Nilai salinitas di daerah penelitian pada saat sebelum tanggul selesai dirampungkan pada bulan Februari 2020 menunjukkan bahwa nilai salinitas dari arah Muara Bedahan menuju ke hulu Sungai Bedahan sejauh 3 $\mathrm{km}$ semakin kecil dengan kontur yang semakin renggang namun di tengah perjalanan kontur merapat. Kontur yang rapat ini menunjukkan bahwa terjadi perubahan nilai salinitas yang signifikan pada jarak pertengahan lokasi penelitian, tepatnya pada ujung cabang pertemuan antara Sungai Bedahan dengan Sungai Sragi Baru di sekitar stasiun 11 dan 12.

Berdasarkan hasil pengolahan sebelum tanggul selesai, terlihat nilai salinitas yang sangat variatif dan semakin rendah menuju hulu lokasi penelitian. Hal ini terlihat dengan nilai terendah salinitas yaitu $6,10 \mathrm{ppt}$ yang berada di stasiun 2 dan 4 pada kedalaman 0,2d dengan stasiun 2 sedalam $0,16 \mathrm{~m}$ dan stasiun 4 pada kedalaman $0,24 \mathrm{~m}$. Nilai salinitas tertinggi yaitu $27 \mathrm{ppt}$ berada di stasiun 20 dan 21 pada 0,8d dengan kedalaman 1,84 m. Nilai rata-rata dari salinitas sebelum tanggul selesai dibangun ini yaitu 13,46. 

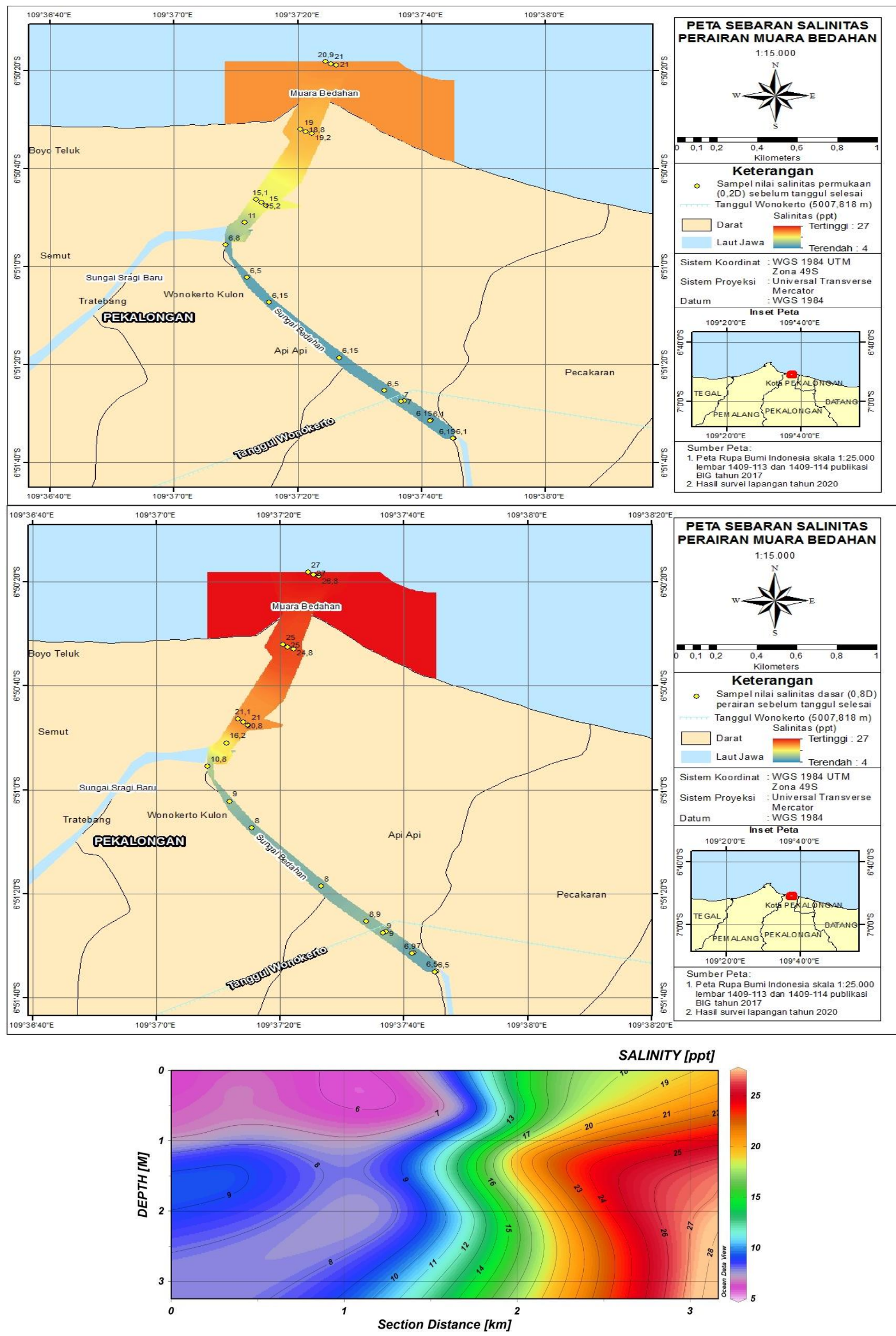

Gambar 2. ODV sebelum tanggul selesai 
Tabel 1. Hasil sebelum tanggul selesai

\begin{tabular}{|c|c|c|c|c|}
\hline Stasiun & Kedalaman & $\begin{array}{l}\text { Salinitas } \\
\text { (ppt) }\end{array}$ & Latitude & Longtitude \\
\hline \multirow[t]{2}{*}{1} & 0,16 & 6,15 & $-6,85972549951548$ & 109,629233032465 \\
\hline & 0,64 & 6,50 & $-6,85972549951548$ & 109,629233032465 \\
\hline \multirow[t]{2}{*}{2} & 0,16 & 6,10 & $-6,85974081181433$ & 109,629180058836 \\
\hline & 0,64 & 6,50 & $-6,85974081181433$ & 109,629180058836 \\
\hline \multirow[t]{2}{*}{3} & 0,24 & 6,15 & $-6,85871222368876$ & 109,628201387822 \\
\hline & 0,96 & 7,00 & $-6,85871222368876$ & 109,628201387822 \\
\hline \multirow[t]{2}{*}{4} & 0,24 & 6,10 & $-6,85875150314664$ & 109,628146402537 \\
\hline & 0,96 & 6,90 & $-6,85875150314664$ & 109,628146402537 \\
\hline \multirow[t]{2}{*}{5} & 0,30 & 7,00 & $-6,85760241122661$ & 109,626981988549 \\
\hline & 1,20 & 9,00 & $-6,85760241122661$ & 109,626981988549 \\
\hline \multirow[t]{2}{*}{6} & 0,30 & 7,00 & $-6,85764934695898$ & 109,626852907240 \\
\hline & 1,20 & 9,00 & $-6,85764934695898$ & 109,626852907240 \\
\hline \multirow[t]{2}{*}{7} & 0,44 & 6,50 & $-6,85702786422724$ & 109,626094177365 \\
\hline & 1,76 & 8,90 & $-6,85702786422724$ & 109,626094177365 \\
\hline \multirow[t]{2}{*}{8} & 0,46 & 6,15 & $-6,85516141389291$ & 109,624068439006 \\
\hline & 1,84 & 8,00 & $-6,85516141389291$ & 109,624068439006 \\
\hline \multirow[t]{2}{*}{9} & 0,44 & 6,15 & $-6,85203067420725$ & 109,620929248631 \\
\hline & 1,76 & 8,00 & $-6,85203067420725$ & 109,620929248631 \\
\hline \multirow[t]{2}{*}{10} & 0,44 & 6,50 & $-6,85061892192039$ & 109,619948901236 \\
\hline & 1,76 & 9,00 & $-6,85061892192039$ & 109,619948901236 \\
\hline \multirow[t]{2}{*}{11} & 0,52 & 6,80 & $-6,84876309877460$ & 109,618966877460 \\
\hline & 2,08 & 10,80 & $-6,84876309877460$ & 109,618966877460 \\
\hline \multirow[t]{2}{*}{12} & 0,80 & 11,00 & $-6,84749913760385$ & 109,619830884039 \\
\hline & 3,20 & 16,20 & $-6,84749913760385$ & 109,619830884039 \\
\hline \multirow[t]{2}{*}{13} & 0,30 & 15,00 & $-6,84653743301098$ & 109,620789438486 \\
\hline & 1,20 & 21,00 & $-6,84653743301098$ & 109,620789438486 \\
\hline \multirow[t]{2}{*}{14} & 0,30 & 15,20 & $-6,84637265477098$ & 109,620571173727 \\
\hline & 1,20 & 20,80 & $-6,84637265477098$ & 109,620571173727 \\
\hline \multirow[t]{2}{*}{15} & 0,30 & 15,10 & $-6,84621420129864$ & 109,620344862341 \\
\hline & 1,20 & 21,10 & $-6,84621420129864$ & 109,620344862341 \\
\hline \multirow[t]{2}{*}{16} & 0,50 & 19,20 & $-6,84246656161210$ & 109,622836299240 \\
\hline & 2,00 & 24,80 & $-6,84246656161210$ & 109,622836299240 \\
\hline \multirow[t]{2}{*}{17} & 0,50 & 18,80 & $-6,84236569650268$ & 109,622556678950 \\
\hline & 2,00 & 25,00 & $-6,84236569650268$ & 109,622556678950 \\
\hline \multirow[t]{2}{*}{18} & 0,50 & 19,00 & $-6,84222721499759$ & 109,622340090572 \\
\hline & 2,00 & 25,00 & $-6,84222721499759$ & 109,622340090572 \\
\hline \multirow[t]{2}{*}{19} & 0,46 & 21,00 & $-6,83858740065610$ & 109,623948745429 \\
\hline & 1,84 & 26,80 & $-6,83858740065610$ & 109,623948745429 \\
\hline \multirow[t]{2}{*}{20} & 0,46 & 21,00 & $-6,83850750685299$ & 109,623711034655 \\
\hline & 1,84 & 27,00 & $-6,83850750685299$ & 109,623711034655 \\
\hline \multirow[t]{2}{*}{21} & 0,46 & 15,00 & $-6,83838034252216$ & 109,623471312224 \\
\hline & 1,84 & 27,00 & $-6,83838034252216$ & 109,623471312224 \\
\hline
\end{tabular}

Hasil pasang surut Februari 2020 diperoleh nilai formzahl sebesar 0,94 dengan tipe pasang surut campuran condong harian ganda dengan MSL (Mean Sea Level) 143, 38 cm, HHWL (Highest High Water Level) 193,47 cm, dan LLWL (Lowest Low Water Level) 107,13 cm. 


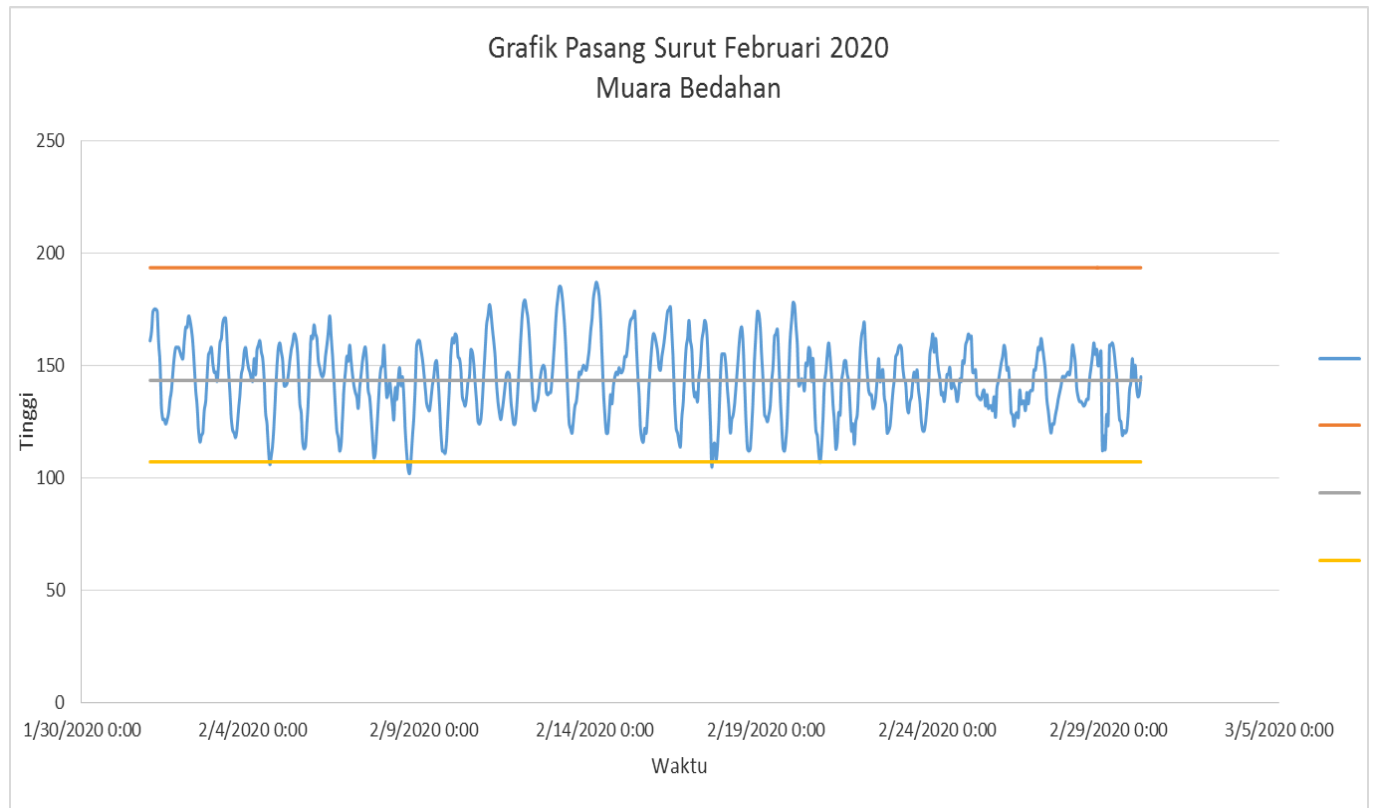

Gambar 3. Grafik Pasang Surut Muara Bedahan Februari 2020

\section{Salinitas Muara Bedahan Setelah Tanggul Selesai}

Hasil pengambilan contoh pada saat sesudah tanggul selesai dibangun, tepatnya pada bulan Juni 2020 menunjukkan bahwa nilai salinitas dari arah Muara Bedahan menuju ke hulu Sungai Bedahan sejauh $3 \mathrm{~km}$ semakin kecil dengan kontur yang semakin renggang. Pada pertengahan lokasi penelitian, antara stasiun 11 hingga 14, kontur salinitas cenderung rapat. Kontur yang rapat ini menunjukkan pada terjadi perubahan nilai salinitas yang signifikan pada ujung cabang pertemuan Sungai Bedahan dan Sungai Sragi Baru hingga mendekati pelabuhan kapal nelayan.

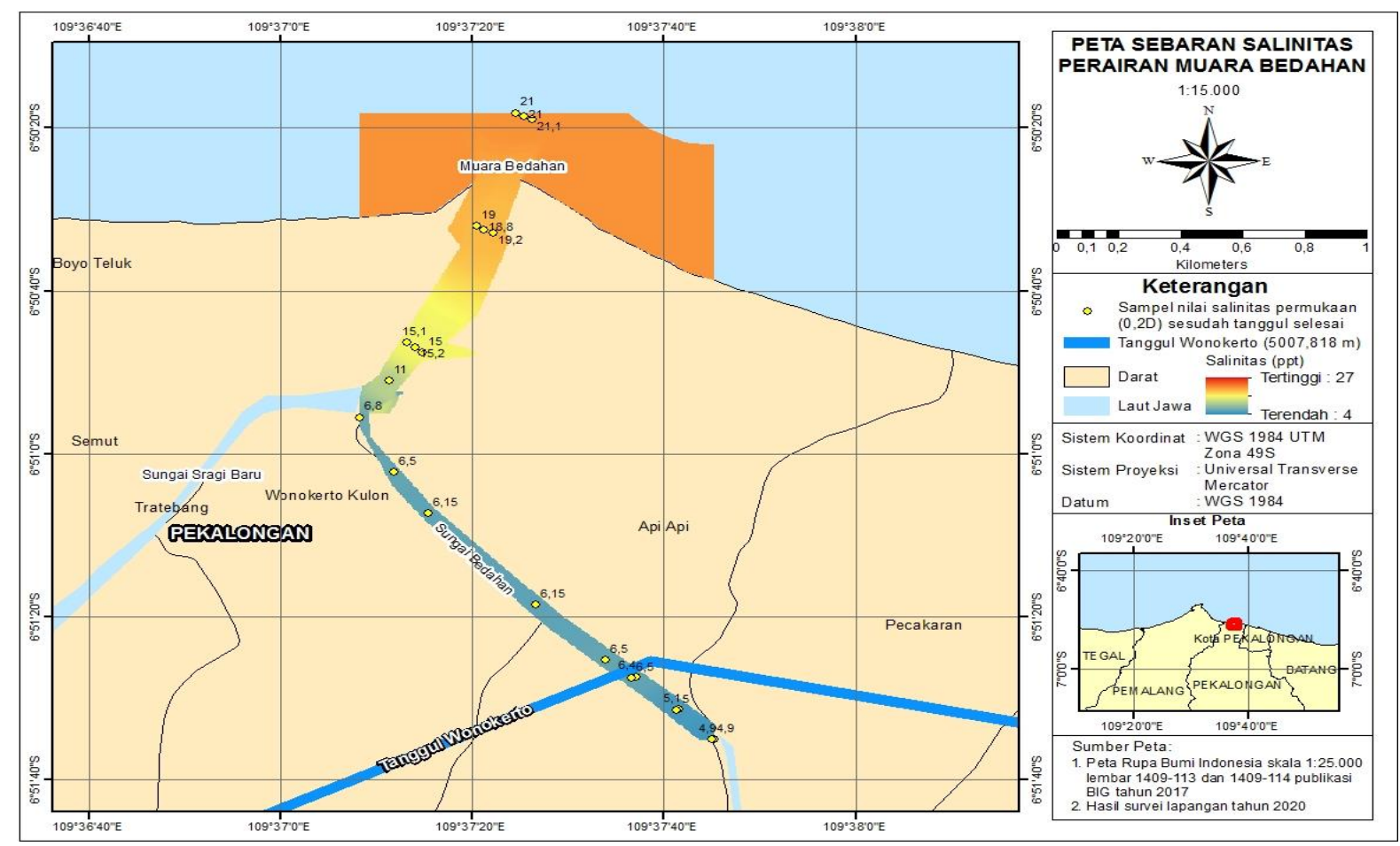



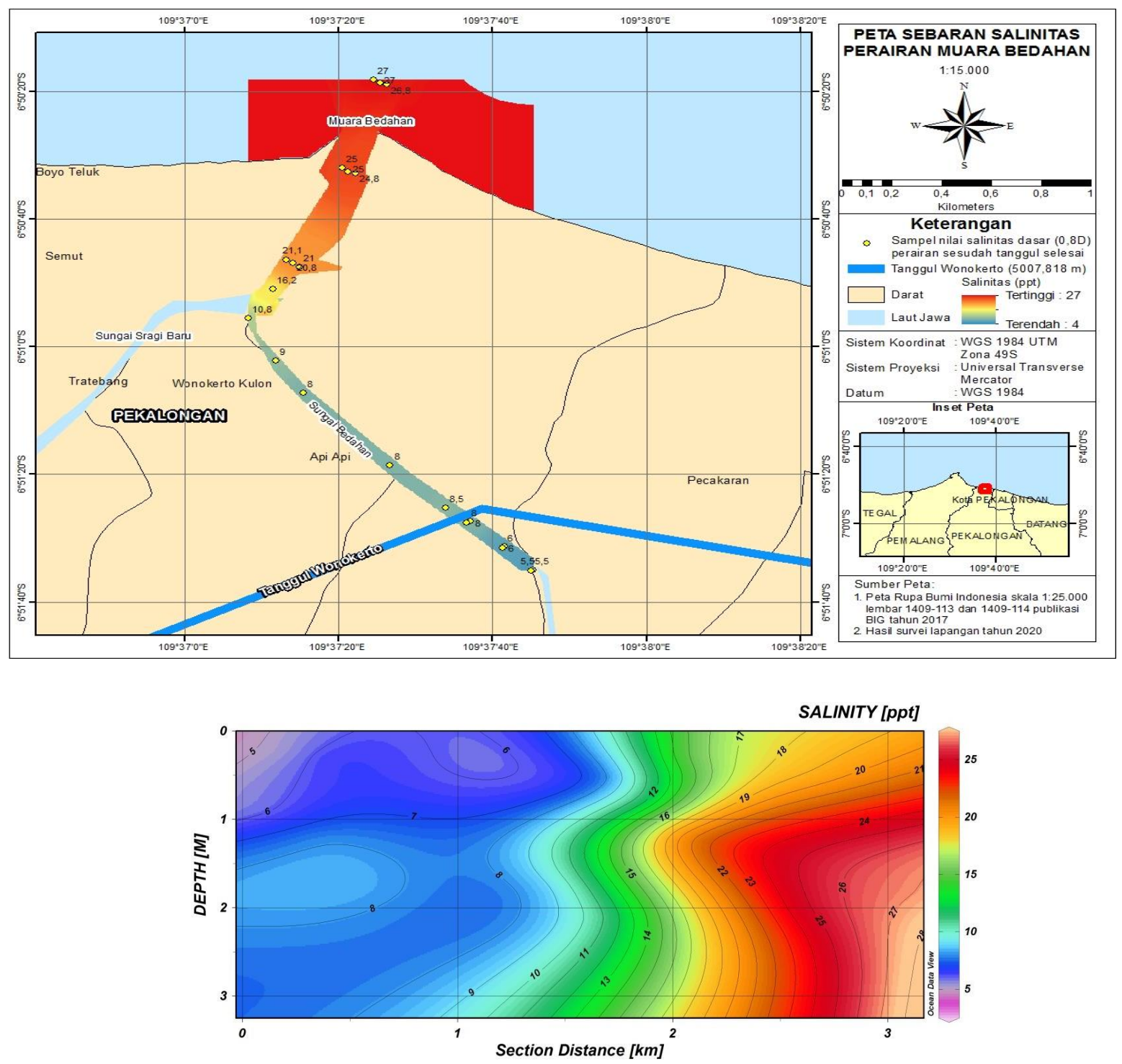

Gambar 4. ODV setelah tanggul selesai

Berdasarkan hasil pengolahan sesudah tanggul selesai, nilai salinitas stasiun 6 hingga menuju hulu lokasi penelitian lebih rendah daripada saat pengambilan contoh sebelum tanggul selesai dibangun (Tabel 1), hal ini ditunjukkan dengan nilai salinitas terendahnya mencapai 4,9 ppt yang terletak pada stasiun 1 dan 2 pada $0,2 d$ kedalaman $0,16 \mathrm{~m}$. Salinitas tertinggi terletak pada lokasi penelitian setelah lokasi tanggul, menuju muara yaitu di titik akhir stasiun 20 dan 21 di kedalaman 1,84 m dengan nilai salinitas 27 ppt. Rata-rata nilai salinitas sesudah tanggul selesai dibangun sebesar 13,17 ppt.

Hasil pasang surut Juni 2020 diperoleh nilai formzahl sebesar 1,51 dengan tipe pasang surut campuran condong harian tunggal dengan MSL (Mean Sea Level) 163,84 cm, HHWL (Highest High Water Level) 236,18 $\mathrm{cm}$, dan LLWL (Lowest Low Water Level) 99,52 cm.

Perubahan signifikan nilai salinitas yang cenderung terjadi pada sekitar stasiun 11 dan 12 ini dipengaruhi oleh pertemuan cabang sungai, sesuai dengan Maulana dan Sudarmadji (2016) yang diantaranya menyatakan bahwa sungai besar dan cabang sungai yang semakin banyak di muara dapat mempengaruhi nilai salinitas. Selain itu, terdapat pula tempat kapal-kapal nelayan bersandar di samping stasiun 15 yang sejajar dengan stasiun 13 di depan stasiun 12, sehingga lingkungan aktivitas manusia juga ikut mempengaruhi perubahan nilai salinitas Muara Bedahan setelah melewati Tanggul Wonokerto. 
Tabel 2. Hasil setelah tanggul selesai

\begin{tabular}{|c|c|c|c|c|}
\hline Stasiun & Kedalaman & $\begin{array}{l}\text { Salinitas } \\
\text { (ppt) }\end{array}$ & Latitude & Longtitude \\
\hline \multirow[t]{2}{*}{1} & 0,16 & 4,90 & $-6,85972549951548$ & 109,629233032465 \\
\hline & 0,64 & 5,50 & $-6,85972549951548$ & 109,629233032465 \\
\hline \multirow[t]{2}{*}{2} & 0,16 & 4,90 & $-6,85974081181433$ & 109,629180058836 \\
\hline & 0,64 & 5,50 & $-6,85974081181433$ & 109,629180058836 \\
\hline \multirow[t]{2}{*}{3} & 0,24 & 5,10 & $-6,85871222368876$ & 109,628201387822 \\
\hline & 0,96 & 6,00 & $-6,85871222368876$ & 109,628201387822 \\
\hline \multirow[t]{2}{*}{4} & 0,24 & 5,00 & $-6,85875150314664$ & 109,628146402537 \\
\hline & 0,96 & 6,00 & $-6,85875150314664$ & 109,628146402537 \\
\hline \multirow[t]{2}{*}{5} & 0,30 & 6,40 & $-6,85760241122661$ & 109,626981988549 \\
\hline & 1,20 & 8,00 & $-6,85760241122661$ & 109,626981988549 \\
\hline \multirow[t]{2}{*}{6} & 0,30 & 6,50 & $-6,85764934695898$ & 109,626852907240 \\
\hline & 1,20 & 8,00 & $-6,85764934695898$ & 109,626852907240 \\
\hline \multirow[t]{2}{*}{7} & 0,44 & 6,50 & $-6,85702786422724$ & 109,626094177365 \\
\hline & 1,76 & 8,50 & $-6,85702786422724$ & 109,626094177365 \\
\hline \multirow[t]{2}{*}{8} & 0,46 & 6,15 & $-6,85516141389291$ & 109,624068439006 \\
\hline & 1,84 & 8,00 & $-6,85516141389291$ & 109,624068439006 \\
\hline \multirow[t]{2}{*}{9} & 0,44 & 6,15 & $-6,85203067420725$ & 109,620929248631 \\
\hline & 1,76 & 8,00 & $-6,85203067420725$ & 109,620929248631 \\
\hline \multirow[t]{2}{*}{10} & 0,44 & 6,50 & $-6,85061892192039$ & 109,619948901236 \\
\hline & 1,76 & 9,00 & $-6,85061892192039$ & 109,619948901236 \\
\hline \multirow[t]{2}{*}{11} & 0,52 & 6,80 & $-6,84876309877460$ & 109,618966877460 \\
\hline & 2,08 & 10,80 & $-6,84876309877460$ & 109,618966877460 \\
\hline \multirow[t]{2}{*}{12} & 0,80 & 11,00 & $-6,84749913760385$ & 109,619830884039 \\
\hline & 3,20 & 16,20 & $-6,84749913760385$ & 109,619830884039 \\
\hline \multirow[t]{2}{*}{13} & 0,30 & 15,00 & $-6,84653743301098$ & 109,620789438486 \\
\hline & 1,20 & 21,00 & $-6,84653743301098$ & 109,620789438486 \\
\hline \multirow[t]{2}{*}{14} & 0,30 & 15,20 & $-6,84637265477098$ & 109,620571173727 \\
\hline & 1,20 & 20,80 & $-6,84637265477098$ & 109,620571173727 \\
\hline \multirow[t]{2}{*}{15} & 0,30 & 15,10 & $-6,84621420129864$ & 109,620344862341 \\
\hline & 1,20 & 21,10 & $-6,84621420129864$ & 109,620344862341 \\
\hline \multirow[t]{2}{*}{16} & 0,50 & 19,20 & $-6,84246656161210$ & 109,622836299240 \\
\hline & 2,00 & 24,80 & $-6,84246656161210$ & 109,622836299240 \\
\hline \multirow[t]{2}{*}{17} & 0,50 & 18,80 & $-6,84236569650268$ & 109,622556678950 \\
\hline & 2,00 & 25,00 & $-6,84236569650268$ & 109,622556678950 \\
\hline \multirow[t]{2}{*}{18} & 0,50 & 19,00 & $-6,84222721499759$ & 109,622340090572 \\
\hline & 2,00 & 25,00 & $-6,84222721499759$ & 109,622340090572 \\
\hline \multirow[t]{2}{*}{19} & 0,46 & 21,10 & $-6,83858740065610$ & 109,623948745429 \\
\hline & 1,84 & 26,80 & $-6,83858740065610$ & 109,623948745429 \\
\hline \multirow[t]{2}{*}{20} & 0,46 & 21,00 & $-6,83850750685299$ & 109,623711034655 \\
\hline & 1,84 & 27,00 & $-6,83850750685299$ & 109,623711034655 \\
\hline \multirow[t]{2}{*}{21} & 0,46 & 21,00 & $-6,83838034252216$ & 109,623471312224 \\
\hline & 1,84 & 27,00 & $-6,83838034252216$ & 109,623471312224 \\
\hline
\end{tabular}




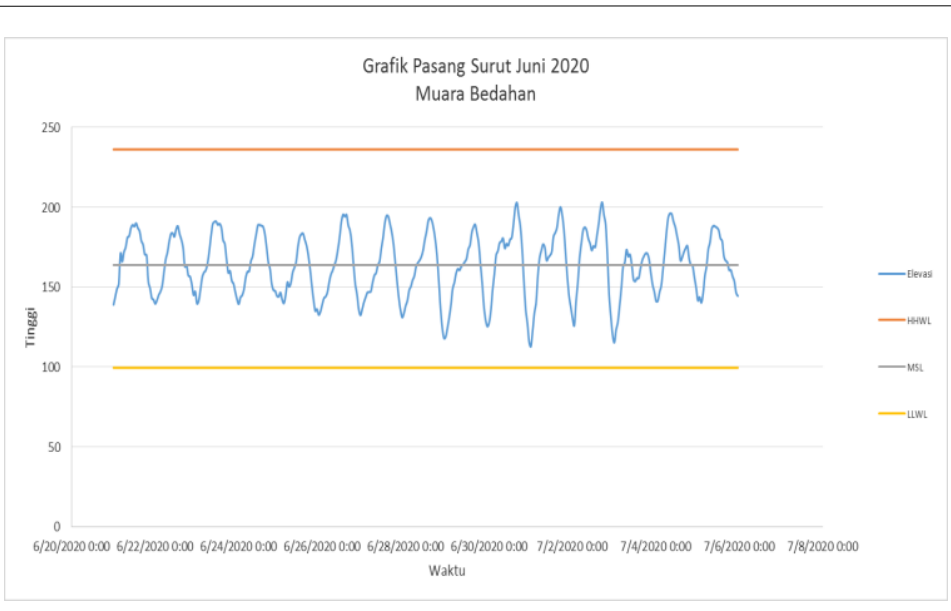

Gambar 5. Grafik Pasang Surut Muara Bedahan Juni 2020

Hasil menunjukkan bahwa sesudah tanggul selesai dibangun, rata-rata nilai salinitasnya lebih rendah dibandingkan rata-rata nilai salinitas muara sebelum tanggul selesai dibangun, terlepas dengan banyaknya pengaruh lingkungan seperti adanya tambak, pemukiman penduduk, hingga kolam pelabuhan nelayan, karena secara umum lingkungan yang dipengaruhi oleh pembangunan Tanggul Wonokerto ini dikhususkan untuk melindungi wilayah sebelum tanggul hingga ke pemukiman penduduk atau dari hulu penelitian hingga posisi tanggul (Stasiun 1 hingga 6). Sebelum tanggul selesai dibangun (Februari 2020), rata-rata nilai salinitas pada stasiun 1 hingga 6 lebih tinggi daripada rata-rata nilai salinitas pada stasiun 1 hingga 6 setelah tanggul selesai dibangun (Juni 2020), sehingga penurunan nilai salinitas perairan ini mempengaruhi kualitas air untuk lingkungan sekitar secara progresif. Berdasarkan Pickard (1963) dalam Putri (2008) menyatakan bahwa lingkungan estuari dapat mengurangi salinitas pada lapisan perairan muara.

Pasang surut pada lokasi muara sangat mempengaruhi nilai salinitas muara, karena berdasarkan Rositasari dan Rahayu (1994), fluktuasi air di dalam perairan muara sangat dipengaruhi oleh pasang surut perairan karena pada umumnya, semakin tinggi amplitudo pasang surut maka semakin tinggi pula potensi produktivitas. Hal ini disebabkan karena gerakan air yang keluar masuk muara sehingga terjadi pengangkutan nutrien dari lingkungan sekitar muara karena cukup banyak aktivitas pesisir, sehingga perubahan nilai salinitas Muara Bedahan ini cenderung diakibatkan oleh pengaruh lokal atau aktivitas lingkungan sekitar muara, karena berdasarkan beberapa penelitian yang telah disebutkan, nilai formzahl tidak terlalu berpengaruh sedangkan ketika tanggul dibangun, dapat menurunkan rata-rata nilai salinitas Muara Bedahan hingga mendekati pemukiman yang dilewati Sungai Bedahan. Tanggul Wonokerto memiliki sistem polder berbentuk longstorage

\section{KESIMPULAN}

Berdasarkan hasil penelitian yang dilakukan di Muara Bedahan, Wonokerto, diketahui tipe estuari Muara Bedahan yang kedalaman maksimalnya $4 \mathrm{~m}$ ini cenderung memiliki tipe homogen vertikal (Vertically homogeneous estuary) dengan distribusi salinitas rata-rata di lapisan permukaan sebelum tanggul selesai 11,47 ppt dan sesudah tanggul selesai 11,2 ppt. Pada lapisan dasar sebelum tanggul selesai 15,44 ppt dan sesudah tanggul selesai 15,4 ppt. Hal ini berkaitan dengan pembangunan tanggul pada wilayah yang melewati Sungai Bedahan dan kedalaman perairan yang mempengaruhi distribusi salinitas.

\section{DAFTAR PUSTAKA}

Maualana, Ilham Erie, dan Sudarmadji, Sudarmadji. 2016. Persebaran Salinitas Airtanah di Kecamatan

Kedung, Kabupaten Jepara, Provinsi Jawa Tengah. Jurnal Bumi Indonesia, 5(1).

Pickard, GL. 1963. Descriptive Physical Oceanography. Pergamon Press, New York.

Putri, Wike Ayu Eka. 2008. Kualitas Air Muara Sungai Batang Arau Sumatera Barat. Jurnal Penelitian Sains, 11(2): $511-519$.

Rositasari, Ricky dan Rahayu, Sri Kusdi. 1994. Sifat-Sifat Estuari dan Pengelolaannnya. Jurnal Oseana, 19(3): $21-31$.

Sudjana. 1992. Metode Statistika. Tarsito, Bandung.

Sugiyono. 2009. Metode Penelitian Kuantitatif, Kualitatif dan R\&D. Alfabeta, Bandung.

Triatmodjo, Bambang. 2008. Hidrologi Terapan. Beta Offset, Yogyakarta. 